\title{
'Stretching the Imagination': Geographical Indications in the EU-Australia FTA Negotiations
}

\author{
Sophie Di Francesco-Mayot \\ EU Centre of Excellence, RMIT University \\ sophie.di.francesco.-.mayot@rmit.edu.au \\ Bruce Wilson \\ EU Centre of Excellence, RMIT University \\ Bruce.Wilson@rmit.edu.au
}

\begin{abstract}
The launch of negotiations for an EU-Australia 'free trade agreement' (FTA) on 18 June 2018 was a confirmation of a 'like-minded' strong partnership, in which both parties had high hopes for an ambitious agreement which would test the new wave of protectionism promoted by Donald Trump. Nonetheless, the initial rounds of negotiations revealed several issues which illustrate the scale of the challenge to be addressed. One such example was the issue of Geographical Indications (GI). The EU and its member states adopt an approach which is highly regulated and prescriptive to safeguard the authenticity of its produce and encourage rural development. Australia approaches this kind of intellectual property issue via a trademark system as well as a sui generis system to better capture the benefits of innovation. This paper analyses the challenges and opportunities an accord on GI's could have for both regions, as revealed in the context of the EU-Australia negotiations. The paper claims that while an agreement on GI's was an significant outcome for the overall FTA, the process adopted by the EU and Australia was in itself a reflection of the ambition for an amicable, dynamic and innovative negotiating process.
\end{abstract}

Key words: Geographical Indications, FTA negotiations, New World approach, Old World approach, Australia, EU, Agreements, Negotiations, TRIPS

\section{Introduction}

Relations between Australia and the European Union (EU) have had a chequered history in trade relations in the last few decades. This was in part due to the restructuring of markets for agricultural produce which followed the United Kingdom's accession to the European Economic Community in 1973. However, their shared experience in multilateral trade negotiations, particularly in the World Trade Organisation, generated a growing sense of shared commitment to the rule of law, and common ambitions with respect to developing more open markets. The launch of negotiations for the EU-Australia 'free trade agreement' (FTA) on 18 June 2018 was an affirmation of a 'like-minded' strong partnership, in which both parties had high hopes for an ambitious agreement which would challenge the new wave of protectionism promoted by Donald Trump. 
Even so, the early rounds of negotiations revealed a number of issues which provoked strong feelings demonstrating the scale of the challenge to be addressed in delivering on this ambition. One such example was the issue of Geographical Indications (GI). In their draft text, the EU sought Australian protection of the legal status of EU GIs, requiring Australian producers to change their product names and labelling. Some Australian producers saw that as a significant threat to their market position and campaigned publicly against this claim. The EU and its member states adopt an approach which is highly regulated and prescriptive to ensure the authenticity of its produce and promote rural development. Australia, on the other, reflected a different approach to this kind of intellectual property, protecting geographical names via a trademark system as well as a sui generis system in order to better capture the benefits of innovation.

However, rather than becoming the object of a typical bartering and compromise process, the parties approached the GIs problem as an opportunity for learning and educating. An extensive consultation process involving both open engagement with sectoral representatives and producers and formal submissions, sought to explore the different understandings and to ensure that all parties, not least business producers themselves, had a shared understanding of the issue, and associated opportunities and costs - 'stretching the imagination', in other words, in order to find an ambitious outcome.

This paper examines the challenges and opportunities an accord on GI's could have for both regions, as revealed in the context of the EU-Australia negotiations. The paper suggests that while an agreement on GI's was an important outcome for the overall FTA, the process adopted by the EU and Australia was in itself a reflection of the ambition for an amicable, dynamic and innovative negotiating process.

\section{Background to the Negotiations}

Australia and the EU have been laying the foundations for a new economic partnership with bilateral agreements relating to trade since the mid-1990s1 (Elijah and O'Neill 2018). The Mutual Recognition Agreement and the Wine Agreement of 1994 (revised in 2008) and the more recent Crisis Management Agreement were signs of easing tensions in trade matters between the EU and Australia. The Rudd Government's decision to sign the Kyoto Protocol was another important initiative which helped to align Australian and EU interests, as did the Gillard Government's decision to join the Asia-Europe Meeting (ASEM), and to seek a treaty-level agreement between Australia and the EU. As Mascitelli and Wilson have noted:

"For decades trade discussions with the European Union (and its predecessors) brought very little comfort or agreement in Australian trading circles. Australian agricultural producers had lost a crucial market when the UK had joined the Common Market and had had to make amends to cover that loss. Over time the global markets changed and Australia's new trade preferences, with Asian partners in particular, were able to compensate for that loss. The EU has re-

${ }_{1}$ Elijah, A., O’Neil, A. 2018. 'Australia and EU Trade: Potential and Pitfalls in a Changing Global Context'. In Mascitelli, B., Wilson, B. (Eds.). 'So Distant, So Close': Australia and the European Union in the 21st Century. Australian Scholarly Publishing, North Melbourne 
emerged as a market of significant interest and the past tensions are being put to bed".2

Apart from their bilateral relationships, experience in the World Trade Organisation provided further evidence that Australia and the EU shared an increasingly consistent position on many aspects of global trade including trade in goods, rules of origin, customs and trade facilitation, services, engaging small and medium-sized enterprises and intellectual property rights. Both had been busy with negotiating other significant FTAs, so sooner or later, it was inevitable that Australia and the EU would commence negotiations. The final step in this preparatory process was completed when their Framework Agreement was concluded in 2017.

For many Australian agricultural industries, an FTA with the EU has the potential to open a market for Australian goods and services of half a billion people and with a GDP of US $\$ 17.3$ trillion3. The dilemma for Australia's dairy industry, however, is that an FTA could present a challenge as the EU is seeking to protect numerous food names through recognition of its Geographical Indications framework.

The EU has registered a range of products as GIs in its meat, dairy, and wine sectors (including over 260 cheeses). It regulates the domestic production and sale of these products within Europe. According to the EU, the GI system aims to support consumer demand for quality foodstuffs in its domestic market and to give EU consumers clear and succinct information on the origins of any foods that they purchase. Over recent decades, it has worked consistently in multilateral and bilateral forums to increase the level of protection afforded to registered EU GI projects (especially dairy)4, such that it has become a core component of the EU's position in all recent negotiations.

The remainder of the paper addresses the following points. Firstly, it outlines the origins of the term 'GI' providing some historical context. It examines the two norms which characterise GIs and the feature which make it unique. Secondly, it discusses the historical development of GIs in the EU focusing specifically on the main treaties and the international agreements which have contributed to its consolidation within the institutional framework of both EU institutions and international bodies such as the World Trade Organisation (WTO).

It then examines the main developments the EU has taken to protect GIs with emphasis on the EU's Framework for the protection of GIs for foodstuff which was established in 1992. It looks at some of the intricacies associated with the three separate types of designation including the 'Protected Designation of Origin' (PDO); the 'Protected Geographical Indication' (PGI); and the 'Traditional Speciality Guaranteed' (TSG). Australia's experience with GIs within the Wine and Grape Industry is explored, focusing on some of the main development.

\footnotetext{
2 Mascitelli, B. and Wilson, B. 2019, 'From protectionism to "free trade", Australia's long road to a trade rules-based order: The Free Trade Agreement with the European Union' Asia-Pacific Journal of EU Studies, Volume 17, number 2, Winter 2019.

3 Dairy Australia 2019, Update on Australia-EU FTA/Geographical Indications, Dairy Australia, viewed 15 June 2019, retrieved: https://www.dairyaustralia.com.au/industry/exports-and-trade/geographical-indications

4 Ibid, 2019.
} 


\section{What are GIs?}

GIs have their origins in 19th century Europes. Countries such as France, Italy and Spain had national schemes that dated back more than 100 years. For centuries, geographical place names have been utilised to convey more than just the geographic origin of food products in European countries6. The issue of Champagne, for example, is one of numerous GIs entangled in an international debate over the appropriate protection of commercially valuable place names. The GI law was developed in France in the early 20th century, motivated by a willingness to protect domestic producers in an increasingly international market. This law underpins the approach of Europeans countries today. The French appellations of origin, for example, is not exclusively about preventing false advertising, but more fundamentally, the policy is driven by the objective of preserving the reputation and character of French regional wineries. In other words, Champagne does not only signify for the French a wine grown in the Champagne region of France, but also wine grown in the Champagne region according to specific practices laid down in law7. In international trade, several treaties have dealt with GIs either directly or indirectly: the Paris convention for the Protection of Industrial Property (1883) and the Lisbon Agreement for the Protection of Appellations of Origin and their International Registration (1958).

As Cleary and van Caenegem note, it was the 1994 World Trade Organisation (WTO) TRIPS agreement which globalised GIs and obliged governments to act to protect GIs 8 . The inclusion of the protection of GIs in the TRIP negotiations during the Uruguay Round of the 'General Agreement on Tariffs and Trade' (GATT) in 1994 has transferred GI issues from national, bilateral or plurilateral matters to the multilateral stage. Moir notes how the TRIPS Agreement incorporates GIs by requiring member states to 'provide the legal means for interested parties to prevent' the use of means 'in the designation or presentation of a good that indicates or suggests that the good in questions originates in a geographical area other than the true place of origin in a manner that misleads the public as to the geographical origin of the good', as well as any use 'which constitutes an act of unfair competition' (Article 22:2)9.

There are two norms for GIs: the 'standard GI privilege' (TRIPS Article 22) which provides the right to exclude others from using the geographic name in a manner which misleads the public; and the 'additional protection for GIs' (TRIPS Article 23) which provides a stronger form of privilege for wines and spirits - qualifiers (like, type, style) are not allowed on labels10. As a type of intellectual property right, GIs are considered 'indications' that identify a good as originating from a specific country, region, locality

\footnotetext{
${ }_{5}$ Cleary, J. \& van Caenegem, W. 2017, 'Mitigating 'One-Size-Fits-All' Approaches to Australian Agriculture: Is There a Case to Be Made for Geographical Indications?', in Cleary, J. \& van Caenegem, W. (eds.) The Importance of Place: Geographical Indications as a Tool for Local and Regional Development, Ius Gentium: Comparative Perspectives on Law and Justice.

6 Watson, K.W. 2016, 'Reign of Terroir: how to Resist Europe's Efforts to Control Common Foods Names as Geographical Indications', Policy Analysis, no.787, pp.1-16.

7 Watson, K.W. 2016, 'Reign of Terroir: how to Resist Europe's Efforts to Control Common Foods Names as Geographical Indications', Policy Analysis, no.787, pp.1-16.

${ }_{8}$ Cleary, J. \& van Caenegem, W. 2017, 'Mitigating 'One-Size-Fits-All' Approaches to Australian Agriculture: Is There a Case to Be Made for Geographical Indications?', in Cleary, J. \& van Caenegem, W. (eds.) The Importance of Place: Geographical Indications as a Tool for Local and Regional Development, Ius Gentium: Comparative Perspectives on Law and Justice.

${ }_{9}$ Moir, H. 2015, Geographic Indications: heritage or terroir? Paper presented at the 10th Annual Conference of the EPIP Association: European Policy for Intellectual Property, University of Glasgow, 2-3 September 2015. 1o Moir, H. 2017a. 'Understanding EU Trade Policy on Geographical Indications' Journal of World Trade, vol.51, no.6, pp.1021-1042.
} 
in that territory where a given quality, reputation or another characteristic of that good is attributable to that geographic origin time 11 . The attributes of the good may derive from either the method of production, the ingredients used in the environment or agricultural features of the region which give the product its distinctive qualities or a strong reputation that may have developed in the region for producing a particular good of a certain quality over time12. Moir notes how the product characteristics must derive from the land and climate ('terroir') 13.

\section{The EU and GIs}

The EU is currently the dominant holder of protected GIs, following its adoption of a framework for the protection of GIs for foodstuff in 1992. This built on the systems already in place in a few member countries. The system was revised in 2006, following a dispute brought against the EU by Australia and the USA to the WTO. It was revised again in 201214.

The system identifies three separate types of designation: the first is the 'Protected Designation of Origin' (PDO) whereby foodstuffs must be produced, processed, and prepared within the specific geographical area. The product's quality of characteristics must also be from that area. The second is the 'Protected Geographical Indication' (PGI) which requires production, processing, or preparation in the geographical area, and the quality, reputation or other characteristics of the foodstuffs to be attributable to that area. The third is the 'Traditional Speciality Guaranteed' (TSG). Moir 15 explains that while PDOs were introduced in 1919 and derive from the French 'Appellation d'Origine Controlee' (AOC) system with origins in consumer protection, the PGI system has its origins in Germany and is based on unfair competition laws and the judicial development of product reputation protection.

In 2019, the EU has registered more than 1,000 GIs in its meat, dairy, and wine sectors (including over 260 cheeses). It regulates the domestic production and sale of these products within Europe. According to the EU, the GI system aims to support consumer demand for quality foodstuffs in its domestic market and to give EU consumers clear and succinct information on the origins of any foods that they purchase.

They are used extensively and effectively by EU member states as a rural and regional development tool 16 . The GI policy is administered by the 'Directorate-General' (DG) for Agriculture and Rural Development. Within the framework of the Common Agricultural Policy (CAP), the EU provides a range of market support measures, including a quality policy. The core of the quality policy is the GI policy, whose main

\footnotetext{
${ }_{11}$ Ibid, 2019.

${ }_{12}$ Ibid, 2019.

${ }_{13}$ Moir, H. 2015, Geographic Indications: heritage or terroir? Paper presented at the 10th Annual Conference of the EPIP Association: European Policy for Intellectual Property, University of Glasgow, 2-3 September 2015.

${ }_{14}$ Moir, H. 2017a. 'Understanding EU Trade Policy on Geographical Indications' Journal of World Trade, vol.51, no.6, pp.1021-1042.

${ }_{15}$ Moir, H. 2017a. 'Understanding EU Trade Policy on Geographical Indications' Journal of World Trade, vol.51, no.6, pp.1021-1042.

${ }_{16}$ Moir, H. 2015, Geographic Indications: heritage or terroir? Paper presented at the 1oth Annual Conference of the EPIP Association: European Policy for Intellectual Property, University of Glasgow, 2-3 September 2015.
} 
objectives include guaranteeing quality to consumers (reducing consumer confusion) and obtaining fair prices for farmers 17 .

There have been several initiatives to promote the use of GIs within the EU. Over the past two decades, there have been significant increases in the number of registered PDOs and PGIs. For example, from 1993 to the end of 2012, PDOs increased by 19 per cent and PGIs by 40 per cent 18 . Recently, the EU has begun to consider extending GIs to non-agricultural products 19 .

\section{Australia and GIs: Wine Agreements of 1994 and 1998}

The use of GIs in Australia began in 1993 when the Australian Wine and Brandy Corporation Act (1980) was updated to enable Australia to fulfil its Agreements with the European Community (EC) on Trade in Wine and the TRIPS Agreement. GIs are currently applied to wine regions: 109 Australian wine GIs are protected in Europe under the 1994 TRIPS Agreement. The Act serves to 'provide the legal means for interested parties to prevent use of a GI identifying wines not originating in a place indicated by the GI in question'20. As Friedmann 21 notes, the GI system is designed to protect the use of the regional names under international law and is governed by the 'Geographical Indications Committee' (GIC), overseen by Wine Australia, with powers to determine GIs and to provide legal certainty over the boundary of a given wine region 22 .

Wine is a significant industry in Australia, affecting numerous regional economies. In 1994, Australia and the European Community (EC) signed the 'Agreement between Australia and the European Community on Trade in Wine, and Protocol' ('the 1994 Agreement'). It was the first wine agreement signed outside of European countries which has treaty status. Underpinning this agreement was a harmonisation of winemaking practices. On 1 December 2008, the agreement was renegotiated and signed in Brussels. It required Australia to discontinue an enhanced list of European regions and extend protection to traditional expressions. The protected names include terms such as Bordeaux, Burgundy, Champagne, Chablis, Port, Sherry and Tokay23.

The wine industry in Australia is the only industry that has the option of registering a GI under legislation specially dedicated to that purpose, namely Part VIB of the Australian Grape and Wine Authority Act 201324. The trade incentive for Australia to continue negotiating with the EU over wine is significant. In 2008 the then Minister

\footnotetext{
${ }_{17}$ Moir, H. 2017a. 'Understanding EU Trade Policy on Geographical Indications' Journal of World Trade, vol.51, no.6, pp.1021-1042.

${ }_{18}$ Moir, H. 2015, Geographic Indications: heritage or terroir? Paper presented at the 1oth Annual Conference of the EPIP Association: European Policy for Intellectual Property, University of Glasgow, 2-3 September 2015.

${ }_{19}$ Ibid, 2017.

${ }_{20}$ Simson, F. 2019. Food naming rights: it's not just fetta, it's our farming free-trade future, viewed 11 June 2019, retrieved https://www.afr.com/news/economy/its-not-just-fetta-its-our-freetrade-future-20190214-h1b9ot.

${ }_{21}$ Friedman, D. 2018, 'Geographical Indications in the EU, China and Australia, WTO Case Bottling Up Over Prosecco', in Chaisse, J., European Integration and Global Power Shifts: What Lessons For Asia?, Peking University School of Transnational Law Research Paper no. 18-14.

22 van Caenegem, W., Drahos, P. and Cleary, J. 2015, Provenance of Australian food products: is there a place for Geographical Indications? RIRDC 15/060: Rural Industries Research and Development Corporation http://rirdc.infoservices.com.au/downloads/15-06o.

${ }_{23}$ Dechent, S., Sadler, P. 2010. 'Geographical Indications in the Wine Industry', The Wine Industry, vol.12, pp.3-9. ${ }_{24}$ Cleary, J. \& van Caenegem, W. 2017, 'Mitigating 'One-Size-Fits-All' Approaches to Australian Agriculture: Is There a Case to Be Made for Geographical Indications?', in Cleary, J. \& van Caenegem, W. (eds.) The Importance of Place: Geographical Indications as a Tool for Local and Regional Development, Ius Gentium: Comparative Perspectives on Law and Justice.
} 
for Agriculture, Tony Burke, pointed out that the European Community had in 2007o8 accounted for about 50 per cent of Australia's wine exports, worth about $\$ 1.3$ billion $_{25}$.

In the 2010 Agreement, Australia came to the table with more than 100 of its own registered GIs for which it was able to obtain protection in the European market. Australia's experience with wine GIs illustrates that for an industry to change the way it labels its produce requires careful management and a long implementation period 26 .

\section{Australia, GIs and the FTA Negotiations with the EU}

More generally, Australia protects geographical names via its trademark system, but also via a sui generis system. The policy question relating to whether Australia should introduce a GI registration system for non-wine food products has been approached through the lens of Australia's agenda in trade negotiations, including with the WTO. According to European policy thinking, GIs could offer rural regions development benefits such as better incomes for farmers and increased employment opportunities for future generations 27. Currently in Australia, there are several ways in which a regional or local name can be protected:

- GI registration if the product is wine;

- Registration as a certification mark;

- Registration of a place name as an ordinary or standard trademark;

- Reliance on consumer deception laws and passing off.

Australia's approach to GIs has largely been influenced by perceptions of the possible trade gains and losses and the implications it could have on national measures of wealth such as GDP rather than domestic consideration of the impact GIs could have on the economic and social development of Australia's 'regional, rural and remote' (RRR) places. Although Australia was one of the first countries to sign a bilateral agreement with the EU for the protection of GIs in the context of the wine trade, this agreement was done from the perspective of protecting Australia's growing exports of wine to the EU.

Despite initial steps towards GI protection, in the Doha Round, Australia has remained an opponent of the broader GI protection being proposed by the $\mathrm{EU}_{28}$ and refuses to consider any extension of strong-form GIs beyond wines and spirits. Australia could commence domestic consultation and a reform process to identify a GI strategy that could address and respond to Australian interests and meet the EU's demands29. This

${ }_{25}$ Burke, T. 2008. 'European deal improves trade access for Australian wines', viewed 22 July 2019, retrieved: http://www.maff.gove.au/burke_media_erleases/2008/december_2008/european_deal_improves_trade_acces s_for_austrlaian_wines.html.

${ }_{26}$ Cleary, J. \& van Caenegem, W. 2017, 'Mitigating 'One-Size-Fits-All' Approaches to Australian Agriculture: Is There a Case to Be Made for Geographical Indications?', in Cleary, J. \& van Caenegem, W. (eds.) The Importance of Place: Geographical Indications as a Tool for Local and Regional Development, Ius Gentium: Comparative Perspectives on Law and Justice.

${ }_{27}$ Van Caenegem, W., Drahos, P., Cleary, J. 2014, 'Pride and Profit: Geographical Indications as Regional Development Tools in Australia', Journal of Economic and Social Policy, vol.16, no.1.

${ }_{28}$ Cleary, J. \& van Caenegem, W. 2017, 'Mitigating 'One-Size-Fits-All' Approaches to Australian Agriculture: Is There a Case to Be Made for Geographical Indications?', in Cleary, J. \& van Caenegem, W. (eds.) The Importance of Place: Geographical Indications as a Tool for Local and Regional Development, Ius Gentium: Comparative Perspectives on Law and Justice.

29 Ibid, 2017. 
would necessitate an evaluation of the value of certification marks for GI policy purposes and examine the reasons underpinning a lack of domestic demand for GIs for foodstuffs $_{30}$. Simson Si $_{31}$ states that one of the factors impeding negotiations for an EUAustralia FTA, is the EU's protectionist agricultural policies. He further claims that GIs along with high tariffs, and small quotas for European farmers, serve to protect European farmers from the volatility of the international market. There is a misconception that if Australia agrees to a stronger-GI system, it would impose restrictions on how Australia farmers market their products.

Over the past 100 years, regional economies dependent upon agriculture have experienced unprecedented change in Australia. Indeed, Alston and Kent ${ }_{32}$ note how the forces of globalisation, the subsequent economic restructuring and deregulation combined with a 'one-size-fits-all' approach to regional policymaking, has resulted in notable implications for regional communities particularly at the local level 33 . Numerous regional, rural and remote communities and the enterprises which underpin their economies, have been forced to 'reinvent' themselves to remain viable, and for their businesses to rethink their business models to remain competitive 34 .

In the EU-Australia FTA negotiations, GIs remain challenging for Australian producers. They perceive trade risks, including the risk that some of the current proposals for extended GI protection for agricultural products could be detrimental to Australia's domestic generic use of European GIs and to its existing trade in goods with other countries agenda 35. Australian policy-makers are concerned that the geographical terms Australia currently freely uses as style descriptors (e.g. Feta, Parmesan, Edam for export cheeses) would be prohibited, and this remains the principal sticking point in Australia's consideration of the WTO GI agenda 36.

On 13 February 2019, the 'National Farmers' Federation' (NFF) led a meeting between Australian farm representatives and the EU Agriculture Commissioner in Canberra. The meeting included delegates from the red meat, grain, dairy, pork, wool, wine, sugar and horticulture sectors. NFF President, Ms Simson, claimed that the meeting was an opportunity to outline Australian agriculture's aspirations for an EU-Australia FTA. She stated that 'Australia and Europe have much in common, we boast proud food and fibre sectors producing in clean, green natural environments'... 'Our citizens are mutually discerning about the food they eat and how it is grown'. A key point of discussion in the meeting was on GIs where Simson claimed that 'from Australian agriculture's point of view, it is critically important that GIs are left out of an EU-

3o Ibid, 2017.

${ }_{31}$ Simson, F. 2019. Food naming rights: it's not just fetta, it's our farming free-trade future, viewed 11 June 2019, retrieved https://www.afr.com/news/economy/its-not-just-fetta-its-our-freetrade-future-20190214-h1b9ot.

${ }_{32}$ Alston, M. \& Kent, J. 2004, Social Impacts of Drought: Report to NSW Agriculture, Centre for Social Research, Charles Sturt University, Wagga Wagga.

${ }_{33}$ Hogan, A., Cleary, J., Lockie, S., Young, M. \& Daniell, K. 2015, 'Localism and the policy of securing the socioeconomic viability of rural and regional Australia', in Hogan, A. \& Young, M. (eds.) Rural and Regional Futures, Routledge, London.

34 van Caenegem, W., Drahos, P. and Cleary, J. 2015, Provenance of Australian food products: is there a place for Geographical Indications? RIRDC 15/060: Rural Industries Research and Development Corporation retrieved: http://rirdc.infoservices.com.au/downloads/15-06o.

35 Van Caenegem, W., Drahos, P., Cleary, J. 2014, 'Pride and Profit: Geographical Indications as Regional Development Tools in Australia', Journal of Economic and Social Policy, vol.16, no.1, pp.1-23.

36 Ballandean Estate Wines. 2019. The Granite Belt Weighs into Geographical Indications (GI) Debate with European Union at Bond University, viewed 4 June 2019, retrieved: https://www.ballandeanestate.com/geographical-indications-gi-debate-eu-bond-university/. 
Australia FTA...any restraint on the use of terms such as fetta, mozzarella or prosecco, would have dire ramifications for our dairy farmers and winemakers in particular' 37.

While some Australian policy-makers and agricultural industries may be apprehensive towards the implementation of strong GIs beyond wines and spirits, the EU claims that GIs have the potential to not only reduce consumer confusion but more importantly, raise incomes for Australian rural producers and subsequently, contribute to regional prosperity. Moreover, under Australia's current trademark system, proposals for a certification trademark system must be scrutinised by the Australian Competition and Consumer Commission. The EU would prefer Australia to move away from a trademark system for registering GIs. However, Moir and Cheng 38 , note how the EU's stand-alone (sui generis) GI registration system does not scrutinise for unnecessary anti-competitive elements before they are registered.

In August 2019, Australia released the list of 172 foods and 236 spirits which the EU wanted protected as part of the FTA. Australia's response to this list was reassurance that Australian interests would be a priority and that stakeholders would do their best to ensure Australian businesses and farmers would get better access to a market engaging 500 million potential consumers" ${ }_{39}$. Among the products on the list were cheeses, confectionaries, olive oils, meats, butters and condiments.

The striking difference in the EU's approach to these negotiations to typical trade discussions has been the extent to which the EU Delegation in Australia has engaged actively with producers and their representatives at all levels. This has included specific stakeholder meetings, invited roundtables, and public for a. In these various settings, EU representatives (including members of the negotiating team) have not only sought to explain the nature of the EU's GI system and its specific linkage with place and history but also to canvas the concerns of Australian producers.

In these processes, the principal concerns of Australians have related to their implications for Australian domestic markets, and the capacity of local producers to compete with European imports where they will have to change their labelling. Specific issues have been raised with respect to the extent to which GIs might intrude into the English translation of European place names, the use of labelling which evoked European heritage, and to the possible expansion of the existing list of GIs over time 40. Producers whose marketing seeks to maximise the benefits of 'provenance', linking the quality of their produce (and potential price) with their environment have shown more interest in the possible benefits of a GI system. The experience of Australian wine producers has been helpful in exploring this possible outcome.

Alongside these various events, the Australian Department of Foreign Affairs and Trade has conducted its own consultations with industry representatives, including a website to which any representative or producer can submit their concerns. According

${ }_{37}$ National Farmers' Federation. 2019. Farmers meet with EU Agriculture Commissioner, warn GIs are a no-go, Viewed 4 June 2019, accessed https://www.nff.org.au/read/6302/farmers-meet-with-eu-ag-commissioner.html. ${ }_{38}$ Moir, V.J. \& Cheng, W. 2018, 'Intellectual Property: main Demand in EU Trade treaties', in, Elijah, A. \& Baker, T. Understanding EU Trade: A Guide For Stakeholders, The Australian National Centre for European Studies, Canberra.

${ }_{39}$ Elliott, L. Branding cheese as feta and gruyere may be banned in Australia under EU deal, The Guardian, viewed 14 August, retrieved: https://www.theguardian.com/business/2019/aug/13/branding-cheese-as-feta-andgruyere-may-be-banned-in-australia-under-eu-deal.

40 From notes recorded by co-author Wilson at a GIs roundtable in Gippsland, Australia, in September 2019. 
to the 'public objections procedure' concerning the terms proposed by the EU for protection as GI's in Australia, objections should be made based on the following ${ }_{41}$ :

- the name is used in Australia as the common name for the relevant good;

- the name is used in Australia as the name of a plant variety or an animal breed;

- the name is identical to, or likely to cause confusion with, a trademark or GI that is registered or the subject of a pending application in Australia;

- the name is identical to, or likely to cause confusion with, an unregistered trademark or GI that has acquired rights through use in Australia; or

- the name contains or consists of scandalous matter.

This feedback will enable the Australian and EU negotiators to come to the detailed negotiations with a clearer understanding of each other's positions and of possible pathways towards a mutually acceptable outcome.

\section{Historical Value Differences?}

European countries such as France, Spain, Italy, Germany, Portugal, Austria, Greece, Lebanon, Israel, Croatia, Georgia and Romania, considered that the most important qualities of wine were derived from the 'terroir' (land) 42 . This idea of 'terroir' underpins the European's approach and strong GI protection. Europeans see an organic relationship between a product's characteristics and the place it was made. Watson explains how establishing strong GI protection is seen by Europeans as essential to prevent fraud, encourage economic development and ensure fairness 43 . While the French word 'terroir' is literally translated as 'terrain, soil, land or ground', the cultural concept of terroir, as it relates to food and wine, is understood as the product of interrelating natural and human factors 44 . The concept of terroir is critical when attempting to conceptualise and comprehend the difference between the European and Australian approach to the GI debate. GIs 'hold the potential of re-linking production to the social, cultural and environmental aspects of particular places, further distinguishing its product from anonymous mass-produced goods and opening the possibility of increased responsibility to place 45 . In addition to acknowledging the branding of the food products, it is also linked to the unique biophysical properties of specific places such as the altitude, microclimate, native plant species and soil type. Importantly, it is also associated with the cultural practices which have maintained these food products' specificities over generations46. Countries such as Australia, the United States, New Zealand and Chile, who initially started to cultivate the new land for viticulture, tended to focus on mixing certain grape varieties, alcohol level and on improving the methods of producing wine. Terroir was considered of secondary importance. Where Europe's preferred method to protect GIs has been to use a sui

\footnotetext{
41 DFAT 2019, Australia-European Union Free Trade Agreement, viewed 14 August 2019, retrieved: https://dfat.gov.au/trade/agreements/negotiations/aeufta/public-objections-gis/Pages/default.aspx

${ }_{42}$ Friedman, D. 2018, 'Geographical Indications in the EU, China and Australia, WTO Case Bottling Up Over Prosecco', in Chaisse, J., European Integration and Global Power Shifts: What Lessons For Asia?, Peking University School of Transnational Law Research Paper no. 18-14.

${ }_{43}$ Watson, K.W. 2016, 'Reign of Terroir: how to Resist Europe's Efforts to Control Common Foods Names as Geographical Indications', Policy Analysis, no.787, pp.1-16.

44 Trubek, A., 2008, The Taste of Place: A Cultural Journey Into Terroir, University of California Press, Berkeley, CA.

${ }_{45}$ Barham, E., 2003, 'Translating terroir: the global challenge of French AOC labeling', Journal of Rural Studies, vol. 29, pp.127-138.

46 Zapata, A.V. \& Bowen, S. 2009, 'Geographical indications, terroir, and socioeconomic \& ecological sustainability: The case of tequila', Journal of Rural Studies, vol.25, pp.108-119.
} 
generis system, other countries have simply used their existing system of trademark law, via certification or collective trademarks47. As the importance of terroir has come to have greater significance in Australian wine, so producers (not least of other food stuffs) have come to appreciate the potential importance of recognising geography.

\section{The Future of GIs in Australia}

A food GI system for Australia which maximises the possibility of benefits to Australia's regions will require creative design, one that takes account of the distinctive features of Australia's food production systems and values rather than focusing solely on a European model 48 . A GIs framework has the potential to create profit for small and medium-size rural food and wine producers and encourage farmers to stay on the land 49. 'Consumers are increasingly looking for products they can trust, they don't want to eat food that they don't believe in or they don't trust...on average the price of a GI product is 2.23 times more than the price of a non-GI product' 50 . Despite the potential benefits, there remains some scepticism about recognising the EU GIs in Australia, let alone introducing an Australian GI system, as it could mean that Australian producers would not be able to use some European names51.

Underpinning the current negotiations on an FTA between Australia and the EU will be questions on how to reconcile the procedural and philosophical differences surrounding GIs. It is argued that Europe's approach which rests on strong GI protection does not reduce innovation and economic growth as is articulated by some critics, but rather, it protects and promotes the value of the terroir while encouraging regional economic development and fairness among small and medium-sized enterprises. The ongoing rounds of EU-Australia FTA negotiations provide an important opportunity for the EU and Australia to continue deepening and consolidating their bilateral relations while addressing some of the pressing issues surrounding the GI debate. Their commitment to learning, to engaging producers themselves as well as their representatives can only strengthen the prospect that a mutually advantageous outcome might achieved. This in turn will enhance their common ambitions for a rule-based global order in an increasingly problematic multilateral international environment.

\section{Bibliography}

Alston, M. \& Kent, J. 2004, Social Impacts of Drought: Report to NSW Agriculture, Centre for Social Research, Charles Sturt University, Wagga Wagga.

Ballandean Estate Wines. 2019. The Granite Belt Weighs into Geographical Indications (GI) Debate with European Union at Bond University, viewed 4 June 2019, retrieved: https://www.ballandeanestate.com/geographical-indications-gi-debate-eu-bonduniversity/.

47 Ibid, 2018.

48 Van Caenegem, W., Drahos, P. and Cleary, J. 2015, Provenance of Australian food products: is there a place for Geographical Indications? RIRDC 15/060: Rural Industries Research and Development Corporation. http://rirdc.infoservices.com.au/downloads/15-06o.

49 Twomey, S. 2016, Regional tags a tasty option, Wednesday September 21 2016, TheWeeklyTimescom.au. 5o Twomey, S. 2016, Regional tags a tasty option, Wednesday September 21 2016, TheWeeklyTimescom.au ${ }_{51}$ Twomey, S. 2016, Regional tags a tasty option, Wednesday September 21 2016, TheWeeklyTimescom.au. 
Barham, E., 2003, 'Translating terroir: the global challenge of French AOC labeling', Journal of Rural Studies, vol. 29, pp.127-138.

Burke, T. 2008. 'European deal improves trade access for Australian wines', viewed 22 July 2019, retrieved: http://www.maff.gove.au/burke_media_releases/2008/december_2008/european_deal_improves_trade_access_for_australian_wines.ht $\mathrm{ml}$.

Cleary, J. \& van Caenegem, W. 2017, 'Mitigating 'One-Size-Fits-All' Approaches to Australian Agriculture: Is There a Case to Be Made for Geographical Indications?', in

Cleary, J. \& van Caenegem, W. (eds.) The Importance of Place: Geographical Indications as a Tool for Local and Regional Development, Ius Gentium: Comparative Perspectives on Law and Justice.

Dairy Australia 2019, Update on Australia-EU FTA/Geographical Indications, Dairy Australia, viewed 15 June 2019, retrieved: https://www.dairyaustralia.com.au/industry/exports-and-trade/geographical-indications

Dechent, S., Sadler, P. 2010. 'Geographical Indications in the Wine Industry', The Wine Industry, vol.12, pp.3-9.

DFAT 2019, Australia-European Union Free Trade Agreement, viewed 14 August 2019, retrieved: https://dfat.gov.au/trade/agreements/negotiations/aeufta/publicobjections-gis/Pages/default.aspx

Elijah, A., O'Neil, A. 2018. 'Australia and EU Trade: Potential and Pitfalls in a Changing Global Context'. In Mascitelli, B., Wilson, B. (Eds.). 'So Distant, So Close': Australia and the European Union in the 21st Century. Australian Scholarly Publishing, Melbourne.

Elliott, L. Branding cheese as feta and gruyere may be banned in Australia under EU deal, The Guardian, viewed 14 August, retrieved: https://www.theguardian.com/business/2019/aug/13/branding-cheese-as-feta-and-gruyere-may-be-bannedin-australia-under-eu-deal.

Friedman, D. 2018, 'Geographical Indications in the EU, China and Australia, WTO Case Bottling Up Over Prosecco', in Chaisse, J., European Integration and Global Power Shifts: What Lessons For Asia?, Peking University School of Transnational Law Research Paper no. 18-14.

Hogan, A., Cleary, J., Lockie, S., Young, M. \& Daniell, K. 2015, 'Localism and the policy of securing the socio-economic viability of rural and regional Australia', in Hogan, A. \& Young, M. (eds.) Rural and Regional Futures, Routledge, London.

Mascitelli, B. and Wilson, B. 2019, 'From protectionism to "free trade", Australia's long road to a trade rules-based order: The Free Trade Agreement with the European Union' Asia-Pacific Journal of EU Studies, Volume 17, number 2, Winter 2019.

Moir, H. 2015, Geographic Indications: heritage or terroir? Paper presented at the 10th Annual Conference of the EPIP Association: European Policy for Intellectual Property, University of Glasgow, 2-3 September 2015. 
Moir, H. 2017a. 'Understanding EU Trade Policy on Geographical Indications' Journal of World Trade, vol.51, no.6, pp.1021-1042.

Moir, V.J. \& Cheng, W. 2018, 'Intellectual Property: main Demand in EU Trade treaties', in, Elijah, A. \& Baker, T. Understanding EU Trade: A Guide For Stakeholders, The Australian National Centre for European Studies, Canberra.

National Farmers' Federation. 2019. Farmers meet with EU Agriculture Commissioner, warn GIs are a no-go, Viewed 4 June 2019, accessed https://www.nff.org.au/read/6302/farmers-meet-with-eu-ag-commissioner.html.

Simson, F. 2019. Food naming rights: it's not just fetta, it's our farming free-trade future, viewed 11 June 2019, retrieved https://www.afr.com/news/economy/its-notjust-fetta-its-our-freetrade-future-20190214-h1b9ot.

Trubek, A., 2008, The Taste of Place: A Cultural Journey Into Terroir, University of California Press, Berkeley, CA.

Twomey, S. 2016, Regional tags a tasty option, September 21 2016, TheWeeklyTimescom.au.

Van Caenegem, W., Drahos, P. and Cleary, J. 2015, Provenance of Australian food products: is there a place for Geographical Indications? RIRDC 15/o60: Rural Industries Research and Development Corporation retrieved: http://rirdc.infoservices.com.au/downloads/15-06o

Van Caenegem, W., Drahos, P., Cleary, J. 2014, 'Pride and Profit: Geographical Indications as Regional Development Tools in Australia', Journal of Economic and Social Policy, vol.16, no.1

Van Caenegem, W., Drahos, P., Cleary, J. 2014, 'Pride and Profit: Geographical Indications as Regional Development Tools in Australia', Journal of Economic and Social Policy, vol.16, no.1, pp.1-23.

Watson, K.W. 2016, 'Reign of Terroir: how to Resist Europe's Efforts to Control Common Foods Names as Geographical Indications', Policy Analysis, no.787, pp.1-16. 